\title{
White Crocodile as Social Criticism of Polygamy Phenomenon in Curug Dahu Village
}

\author{
Yuda Syah Putra ${ }^{1}$, Irpan Riana ${ }^{2}$ \\ ${ }^{1}$ Fotografi Departement, Politeknik Negeri Media Kreatif \\ Jl. Srengseng Sawah Jagakarsa, Jakarta Selatan 12640 \\ yudasputra@polimedia.ac.id \\ ${ }^{2}$ Fotografi Departement, Politeknik Negeri Media Kreatif \\ Jl. Srengseng Sawah Jagakarsa, Jakarta Selatan 12640 \\ irpan_riana@polimedia.ac.id
}

\begin{abstract}
The purpose of this study was to analyze the structure of the traditional wedding ceremony and the White Crocodile performance in Curug Dahu Village. Signifying the concept of denotation and connotation of the White Crocodile in the traditional wedding ceremony in Curug Dahu Village, and analyzing the relationship between the White Crocodile communication elements to the phenomenon of polygamy in the Curug Dahu village. The research method used is a qualitative research method. The data collection technique was carried out starting with literature study, observation and interviews accompanied by documentation. The object of this research is the White Crocodile in a Sundanese traditional ceremony in Curug Dahu Village. This research uses Roland Barthes' Semiotics theory. Decoding the codes and identifying the denotations that have been formed are obtained at the primary level (denotation), Keywords: White Crocodile, Polygamy, Roland Barthes, Social Criticism.
\end{abstract}

\section{Introduction}

The White Crocodile Show developed precisely in Curug Dahu Village, Serang Regency, Banten Province. Banten Province, which was previously included in the West Java Province. Of course, this means that Banten has a very strong attachment to Sundanese culture. The second-level district of Serang is as generally the second-level district in the Banten residency area in general, such as Lebak Regency, Pandeglang Regency and Tangerang Regency. The area has different characteristics from the Priangan area, which is typical of Sunda, both ethnically and culturally, especially the residents of Serang Regency, and the North Banten area, which mostly uses the Javanese-Banten language. This language is better known as Java Reang, and the conditions are quite different from the situation in southern Banten which usually uses Sundanese, such as in Lebak and Pandeglang regencies. This means that although Javanese culture influences the culture of the Serang community, 
there is a form that maintains Sundanese culture, in this case, Sundanese is used in local performing arts.

The White Crocodile as a performing art originating from the Curug Dahu village is a series of processions leading and parading at the wedding ceremony of the Curug Dahu community. This performance is to escort the groom who comes with all respect and gives thanks for the establishment of friendship between the two parties, so that the wedding atmosphere becomes more lively and intimate. In the performance of the White Crocodile, the accompanying music is rudat music. This music is an art that originated and developed in Banten which also functions as entertainment when accompanying the bride and groom, this music also breathes Islam so that when it is collaborated with the White Crocodile performance it looks very religious. Rudat consists of gending paria ria, kemplongan, and gembrung. Rudat is a traditional art that combines elements of dance, shalawat poetry, and kanuragan, combined with flying wasps and applause. However, in the White Crocodile show, Rudat is not performed as a whole as a Rudat show, meaning that Rudat is played only to accompany the White Crocodile which is combined with folk dances and without poetry or kanuragan or silat. Besides Rudat music, the White Crocodile performance is also supported by folk dances. This dance accompanies the White Crocodile by following the strains of rudat music so that all supporting elements look in harmony. Associated with the style of dance in accompanying the White Crocodile can change according to the development and needs of the community.

White crocodile is a traditional art with Islamic nuances that lives and thrives in Curug Dahu village. This can be seen from the shape shown, which is made and shaped to avoid the realistic form of a crocodile animal. The ingredients used have a useful function for various wedding 
purposes, for example, the betel leaf used to make the white crocodile property can be distributed to mothers who help cook in the kitchen of the wedding party owner. Usually, betel leaves and areca nut together are chewed, which is believed to be beneficial for oral health. Then the fibers of the palm fiber can be used as material for making ropes and brooms, as well as bamboo and wood for cooking. In addition, palm fiber, betel leaf, areca nut, coconut leaf and other ingredients are symbols of hope and gratitude to Allah SWT. The white crocodile is also a symbol of social status, as can be seen from the size of the white crocodile and the number of offerings that symbolize the status of the groom.

Cultural products that are present in society cannot be separated from what is happening in society itself. So that sociologically the creator will be influenced and produce works with codes and symbols for what phenomena are happening. The White Crocodile Show is also an art form, which involves the expression of human emotions and is conveyed to others through symbols in appearance, movement, and sound. The presentation of the White Crocodile show as a means of communication can be seen in the White Crocodile property. The messages in the White Crocodile are conveyed or communicated to the public (audience) through the presentation of performances and visual elements that are realized. From that show, actually the White Crocodile is a way of communicating the values of loyalty that people should know and realize how important these values are in life. The White Crocodile show is full of symbols from the primordial Banten culture, in which it contains various elements such as ritual ceremonies, beliefs, attitudes and behavior patterns, as well as ways of thinking and emotions as religious concepts of the people.

The wedding ceremony and the performance of the White Crocodile as a tradition and the work of art is 
a complex structure. Therefore, to be able to understand the wedding ceremony and the performance of the White Crocodile, it must be analyzed. Researchers have to track and analyze the outer structure (surface structure) as well as the inner structure (deep structure). Thus, the overall meaning of the wedding ceremony and the performance of the White Crocodile will be understood.

"The starting point of the acculturation process between Indonesian and European cultures was the arrival of Portuguese ships in Maluku, namely in Banda, Tidore, and Ternate, then to Nusa Tenggara at the beginning of the 16th century, and the arrival of these ships. Dutch ships from the VOC trading organization in Banten at the end of the 16th century". (Koentjaraningrat, 2009, p. 206).

As a result of the openness of the people of Banten to foreign cultures, it obscures the cultural identity of the people. As happened in the use of the language contained in the wedding ceremony, the majority of the people of Curug Dahu in their daily life use Javanese, but in the procession of the marriage ceremony, the language used is Sundanese. The reconstruction event of the White Crocodile show that occurred in 1993 illustrates the efforts or responses of the community in relation to phenomena in their environment. This effort is an illustration of the ideology of society that has been formed. There are interesting dynamics that occur in the form of the White Crocodile to the aesthetic concept presented, manifested or expressed in relation to the phenomena and social conditions of the Curug Dahu community which are so much influenced by various forms of interesting culture to study.

\section{Theoretical Basis}

The White Crocodile myth in this study is seen as an important part of referential meaning in its capacity as a paradigmatic relation. This study views the White Crocodile as a means of communication that contains the meaning of expression which is constructed from elements 
in a certain structure. The purpose of this structure follows Roland Barthes' view which is based on Saussure's semiology in which Barthes places more emphasis on the sign system (semiotics) or emphasizes the parole aspect (Sunardi, 2004:37-83). These elements are symbols that are loaded with mythical content. Each of these elements is combined in such a way with the aim of accommodating a message or meaning which is a transformation of a concept that is closely related to the meaning of the White Crocodile.

\section{Research Methods}

The qualitative research method used in this study was built with the involvement of the author directly in the field. In this context, the researcher is part of the community as the object of research. And with an ethnicsemiotic approach that examines visual signs and symbols produced by the community as behavior or reflection of social and cultural life in Curug Dahu village as the location of the object of research. The ethnosemiotic method plays more of a role in studying signs and language, not only at the syntactic level but also at the semantic and pragmatic level."Ethno-semiotics is a method that connects text reading with everyday life which is macro in nature" (Yasraf, 2012: 319).In this study, the White Crocodile is seen as a text and code, which is also a number of linguistic symbol units used by the community to realize their experiences, logic, social reality, and at the same time textual/semiotic reality apart from being a structure.

\section{Discussion}

White Crocodile is a show that is performed or held in an open space, but it is not wrong to say that the show is carried out in the most magnificent space. When compared to a performance that is carried out indoors with lights or lights that are made to make the show look good, 
however, the abundance of direct light from the sky that illuminates the White Crocodile show can be understood as a gift and luxury that further builds the emotion of the show.

\section{Image 1} White Crocodile Show

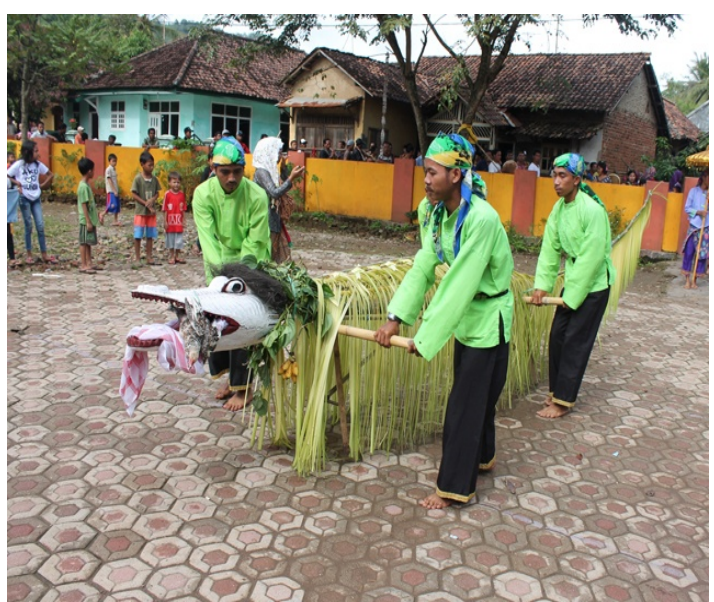

Source: Yuda Syah Putra

Social problems that occur in society are not avoided, on the contrary, society or artists respond to these problems in a work, in this case White Crocodile. "An artist is an impression collector, a supersensitive person who is trained in observing objects and events around him that most people don't pay attention to" (Heriyawati, 2016:13). Based on this opinion, the artist is certainly sensitive to the social reality that is part of his life, then processes it in a work as a reflection of the socio-cultural conditions of his community. It aims not only as an expression of expression, but also as a medium of communication in conveying criticism. It is hoped that the work he has made can improve the situation of the problems that are currently occurring in the community in a persuasive manner. White Crocodile as a work cannot be separated from the role of its creator and the environment in which the show is created.

Social criticism arises along with the occurrence of problems in aspects of social life which include, customs, social interaction, especially in this case married life. Problems can arise if one of the mechanisms is not implemented according to the existing social order in society. Problems or violations committed can present a situation where the community becomes unstable and hinders the goals that have been determined together. In addition to social 
problems as described previously regarding starting marriage, in marriage, every couple is required to obey the norms that apply in society, both in terms of customs passed down from generation to generation and from their religion. One of them is that each partner is required to be faithful, so that when this is awake, married life will remain harmonious. However, when the balance in the household order is violated, it will be disturbed.

Expressing criticism is one way to respond to social problems that often occur in society. "Social criticism is a form of communication in society that aims to control social systems or community processes" (Abar, 1999: 47). As in the White Crocodile show, as a form of performance work that can be used as social control in social life in responding to existing problems, so that it can be used as reflection in social life and obtain solutions. It is hoped that social criticism communicated through works of art can trigger changes in people's lives for the better.

Social problems that occur in society often trigger responses and attention from other community members, including artists, one of which is to pour their ideas and ideas into a work of art that contains elements of criticism. As is the case with the phenomenon of divorce and polygamy in Indonesia today, which is increasing every year. Divorce is a phenomenon of the occurrence of human rights violations, where these violations already have their own measure, namely social values that have been established. In Curug Dahu village, criticism in the form of works of art is in the White Crocodile performance. In addition to containing values and morals, the White Crocodile show is present as a social critique of the phenomenon of divorce and polygamy, which is increasing every year and becomes a concern in society. 
In general, marriage between a man and a woman is known as monogamous marriage, but there is also a form of marriage known as polygamous marriage. Polygamous marriage is when a man is married to more than one woman as his wife. As stated in Article 3 paragraph 2 of the Marriage Law that, "The court may give permission to a husband to take more than one wife if the parties concerned want". Polygamy occurs due to many factors, one of which is due to economic dependence, especially which often occurs in the woman's family.

Conflict in marriage is the beginning of divorce between husband and wife. Disputes that arise due to conflict result in reduced feelings of love and affection for their partners. These conflicts are often caused by several factors, such as economic conditions, lack of education, and factors of disloyalty. There are many more worrying phenomena as a result of divorce, where many married couples divorce without going through a religious court. This makes the rights of the wife and children ignored, as if after the divorce there are no more responsibilities or burdens borne by the husband. This happens because there are no sanctions and supervision from government officials. The increase in the divorce rate from time to time seems to have decreased in its sacred value and divorce is no longer taboo. "The Serang Religious Court, Banten, noted that in the period 2019 to 2020 it had handled 7,000 divorce cases submitted by the plaintiffs, both from wives and husbands." Surprisingly, the applicant who registered the lawsuit was dominated by the wife as the plaintiff.

In addition to the issue of divorce, polygamy is a phenomenon that often occurs in Banten, no wonder there is an expression that men from Banten are dubbed as 'marriers'. Polygamy has a negative impact on the environment, especially the negative impact on 
children and on the first wife as well as other wives. According to the Marriage Law, before committing to polygamy, someone who wants polygamy must first obtain permission from the Religious Courts by submitting application for a polygamy permit. In article 2 of Law no. 7 of 1989 in conjunction with Law no. 3 of 2006 in conjunction with Law no. 50 of 2009 concerning the Religious Courts which reads "Religious Courts are one of the implementers of judicial power for people seeking justice who are Muslim regarding certain civil cases regulated in this law". However, in reality, many people practice polygamy without applying for a permit to the court authorized to give polygamy permits. This makes them voluntarily practice polygamy and a phenomenon like this happens a lot, especially in Banten.

The symbols contained in the White Crocodile are analyzed and positioned as texts containing codes/messages and the cultural attitudes of the people themselves towards the marriage ceremony. White Crocodile is a text that contains messages and cultural attitudes of the community itself, in this context it is seen from the relationship between the text and the experience of the community and the culture of its users, the interaction between the rules that have been mutually agreed upon in the text and the mutually agreed rules experienced and expected by the users. . Then the texts that can be read visually on the White Crocodile as a visual marker. The signs contained in the White Crocodile show can be read as a sign that can be interpreted from a performance that is part of the marriage ritual ceremony. White Crocodile is a form of storytelling or narrative that holds the meaning of a marriage. In this case, the White Crocodile contains solutions in overcoming problems in marriage. Not only solving problems in marriage, even various social events that occur in society are summarized in it. One of them was 
the phenomenon of polygamy which was growing in Banten society at that time. The phenomenon of polygamy in fact has many negative impacts, especially on the rights of wives and children. As a response to public unrest about the phenomenon of White Crocodile polygamy, it is present as a form or method as well as a signal for solving these social problems. In this context the White Crocodile plays a role in providing solutions to the causes of polygamy, such as one of the causes is the wife cannot give offspring. Unable to give offspring one of the factors is due to health problems. White Crocodile is a property made from natural ingredients that can provide health benefits, such as betel leaf for the cleanliness of female intimate organs.

Another meaning is presented in the signs contained in the White Crocodile element. For example, the meaning of loyalty symbolized in the Crocodile figure illustrates how the results of the act of loyalty will produce happiness, prosperity, harmony, and harmony. Furthermore, loyalty will lead to a beautiful life after death, namely heaven. Because disloyalty is a form of suffering.

\subsection{Concept of Denotation and} Connotation

Semiotics aims to explore the basis of a sign system that departs from grammatical rules and regulates the meaning of complex, hidden, and culturally dependent texts. This then raises attention to connotative and denotative meanings or relationships and impressions that are revealed through the use or combination of signs. The first stage of significance is the relationship between the signified and the signified within a sign to external reality. "In semiotic analysis, signification (signification) is the result of a sign. Marking is the content or import of communication" (Hartley, 2010:224). Barthes calls it denotation, which is the most tangible meaning of a sign (Barthes, 2004:162). Denotation is a system 
of meaning in the first stage, explicitly shows the meaning of the phenomena or words that we observe. Denotation is associated with closed meaning" (Sobur, 2009:70). Connotation is a signification is the second stage that describes the relationship that occurs when the sign meets its cultural values and the feelings of the reader. Identifying the markers and markers in the White Crocodile is the first stage. Then, interpreting these signs at the denotative level of meaning and then interpreting them to a further level, namely connotative meaning. This research night marker functions as a foothold and limit for the author in conducting his research. Identifying the markers and markers in the White Crocodile is the first stage. Then, interpreting these signs at the denotative level of meaning and then interpreting them to a further level, namely connotative meaning. This research night marker functions as a foothold and limit for the author in conducting his research. Identifying the markers and markers in the White Crocodile is the first stage. Then, interpreting these signs at the denotative level of meaning and then interpreting them to a further level, namely connotative meaning.

The white crocodile as a symbol of fertility in denotation and connotation is conceptualized on the visual element of the white crocodile property. On the White Crocodile Head the denotation level is a depiction of fertility and human desire when married. On the head of a white crocodile, the connotation level is a reflection of hope and prayer to God so that he will be given offspring and a happy life in this world and in the hereafter. On yellow leaf, denotatively is a form of prayer and hope to get God's pleasure. At the connotative level, janur kuning is a liaison between humans and their God, a place to ask, beg, and hope for something, in this case it is offspring, welfare and household harmony. The denotation level of areca nut is a medicine for men's needs when they are married. 
At the connotation level, areca nut is a symbol of the male figure. In betel leaf the denotation level is the fulfillment of women's health needs. At the connotation level, the betel leaf symbolizes the female figure and its role in achieving a harmonious life. At the level of fibers, the denotation is a cleaning tool. At the level of connotation, palm fiber is a reflection of how important self-evaluation of bad qualities is in order to live a happy and harmonious life. At the denotation level wood is one of the fuels for cooking. At the connotation level, healthy food is important in maintaining a healthy life and maintaining the reproductive system so that the desire for a harmonious and happy married life can be realized, in this case having children.

The white crocodile as a symbol of loyalty is conceptualized in the scene of the show. At the denotation level, the scene shows a patient attitude waiting for a partner. In the first scene, the connotation level shows loyalty, sincerity, patience and does not betray or break promises, but maintains love and love and maintains the relationship that will be built together. In the second scene, the denotation level illustrates that problems will interfere with the journey in building a household. at the level of connotation a happy household does not mean a household without problems, of course problems will always exist but the most important thing is how to find a way out and maintain a household that has been built. In the third scene, the denotation level in building a household will be faced with many disturbances and problems both from within the household and from outside. At the level of connotation with faith and piety to Allah SWT, the household will be maintained even though various conflicts and problems try to destroy and destroy it.

The White Crocodile as a symbol of fertility in denotation and connotation is conceptualized in the 
visual elements of the White Crocodile property and as a symbol of loyalty is conceptualized in the performance scene. This concept shows that the people of Curug Dahu village as Sundanese people in their culture use primordial reasoning.

4.2White Crocodile as a Response to Social Problems in the Community

White Crocodile As a ritual performance in a traditional marriage ceremony, it displays symbols of traditional performances common in Sundanese society, such as dance, music, and media performances. But gently the White Crocodile show does not only hint at its relationship to ritual or religion, but also to the history of Sundanese culture and the social phenomena of society that occurred at that time.

White Crocodile is a discourse formed by the people of Curug Dahu Village as a response to the social problems that occurred at that time. Where people are faced with the problem of polygamy and divorce which continues to increase every year. Anxiety about the impact that occurs due to polygamy and divorce makes the show one of the ways and solutions to reduce the rate of polygamy and divorce. The signs contained in the White Crocodile show can be read as a sign that can be interpreted from traditional performances that are part of a wedding ritual ceremony. White Crocodile is a form of storytelling or narrative that holds the meaning of a marriage.

The White Crocodile as a means of communication is not only a ritual ceremony that presents the meaning of cause and effect from the rational actions of people's lives. In this case the meaning is presented in the signs contained in the White Crocodile element. For example, the meaning of loyalty symbolized in the Crocodile figure illustrates how the results of the act of loyalty will produce happiness, prosperity, harmony, and harmony. Furthermore, faithfulness will lead 
to a beautiful life after death, namely heaven.

White Crocodile is a discourse that exists to maintain and restore norms that have developed in society that are starting to disappear and are no longer obeyed by the community. "The elements of Islam and elements of the original belief (adat-istiadat), seem to have been integrated into a belief system and responded to by them with the same emotion" (Ekadjati, 1984:283). As a medium of da'wah such as piety/carrying out God's commands which are believed to lead to a happy life, in this case having a family. Having offspring and family harmony which at that time was the dream of every couple. The White Crocodile in fact can help understand the mistakes that exist in people's social life. The White Crocodile is a symbol of fertility, which means there is an assumption that people have problems with their reproductive system, either because of their diet or way of life or because of their lack of devotion to God. Likewise, the show talks about loyalty, which means there is also an assumption that people are restless and worried about the forms of disloyalty that exist in their social sphere. Thus White Crocodile in the current context, White Crocodile tends to fulfill people's imagination, that the show is something that can show conditions related to the social problems they face.

\section{Conclusion}

White Crocodile is a typical Sundanese art form that has developed both in form and function. However, the patterns of the old Sundanese traditions have not changed or remain visible as the identity of the people. The changes experienced by the White Crocodile are a manifestation of the character of the Curug Dahu Village community, which is open to other influences and cultures.

The code or message on the White Crocodile refers to the concept of forming the White Crocodile show as a symbol of the 
way of thinking of the people, that the people of Curug Dahu village still believe in magical powers which are considered to be able to influence the whole journey of their lives. The denotations that have been formed are obtained by the White Crocodile as a symbol of fertility which is conceptualized in the visual element of the White Crocodile property and as a symbol of loyalty is conceptualized in its performance scene. This concept shows that the people of Curug Dahu village as Sundanese people in their culture use primordial reasoning. From these results, The author will analyze criticism as a message contained in the White Crocodile which must be understood as something that serves to express and provide justification for the dominant values prevailing at that time. These connotations will form a paradigmatic relationship.

The results of identifying the denotations that have been formed are obtained in the second meaning, at the primary level (denotation), White Crocodile is an image of fertility and fidelity in marriage, while at the secondary level of meaning (connotation) White Crocodile is an effort to carry out religious orders. In this case, Islam is the majority in the Curug Dahu Village community. White Crocodile in this context is a response to a social phenomenon, namely polygamy in the Curug Dahu village community.

As a research model for the study of wedding ceremonies and performances of the White Crocodile as a traditional art through Roland Barthes' semiotic analysis, it can help understand the cultural phenomena of the people of his time. Then it can be used as a reflection by readers or society and can be applied in everyday life. And this research would be able to contribute ideas towards solving social problems in society, such as the phenomenon of polygamy and divorce in society. The phenomenon of polygamy in society is the 
concern and thought of the creator/artist to pour his ideas and ideas into a work of art that contains elements of criticism. The form of criticism conveyed in the performance art of White Crocodile is carried out directly and indirectly. Using simple and clear language is a criticism that is conveyed directly to the social problems that occur in the community. One of the direct criticisms is conveyed in sawer as one of the stages in the show, where the criticism is in the form of advice and advice on how to live a married life. Submission of indirect criticism is done in a symbolic way, such as the form of the White Crocodile as a symbol of loyalty. As already mentioned, one of the most common divorce factors is infidelity. The White Crocodile Show is considered by the public as the right medium in an effort to convey criticism of the social phenomena that occur.

\section{References}

Abar, Ahmad Zaini. 1999. Kritik Sosial, Pers, Politik Indonesia dalam Kritik Sosial dalam Wacana
Pembangunan. Yogyakarta: UII Press.

Ani Nursalikah, Pengadilan Agama Serang Tangani 7.000 Kasus Perceraian.

(https://www.republika.co.id/berit a/qd9554366/pengadilan-agamaserang-tangani-70oo-kasusperceraian) Diakses tanggal 16 Maret 2021, Pukul 10.45 WIB. Barthes, Roland. 2004. Mitologi. Yogjakarta: Kreasi Wacana.

Barthes, Roland. 2006. Petualangan Semiologi, Yogjakarta: Pustaka Pelajar.

Departemen Pendidikan dan Kebudayaan, Upacara Tradisional daerah Jawa Barat, Perpustakaan Nasional Indonesia, 1982-1983.

Ekadjati, E.S. 1984. Masyarakat Sunda dan Kebudayaannya, Jakarta: PT. Girimukti Pasaka.

Fiske. 2010. John, Cultural and Communication Studies Sebuah Pengantar Paling Komprehensif, Bandung : Jalasutra.

Hartley. 2004. Jhon, Communication, Cultural, \& Media Studies, Yogjakarta: Jalasutra.

Heriyawati, Yanti. 2006. Seni Pertunjukan dan Ritual, Yogyakarta: Penerbit Ombak.

Koentjaraningrat. 1992. Kebudayaan, Mentalitas dan Pembangunan, Jakarta:Gramedia. Mahkamah Agung RI Direktorat Jenderal Badan Peradilan Agama. 20110. Pedoman Pelaksanaan Tugas dan Administrasi Peradilan Agama. Nasr, S.H. 1993. Spiritulitas dan Seni Islam, Bandung: Mizan Permana.

Piliang, Yasraf Amir. 2003. Hipersemiotika: Tafsir Cultural 
Studies Atas Matinya Makna, Bandung: Jalasutra, 2003.

Sausurre, F.D. 1996. Pengantar Linguistik Umum, Yogjakarta: Gajah Mada University Press.

Sobur, A. 2009. Semiotika Komunikasi, Bandung: Remaja Rosda Karya.

Storey, Jhon, 2010. Cultural studies dan Kajian Budaya Pop, Yogjakarta: Jalasutra.

Sumardjo, Yakob. 2014. Estetika Paradoks, Bandung: Kelir Suryani. Sunardi, ST. 2004. Semiotika Negativa, Yogyakarta: Penerbit Buku Baik. 